\title{
WPLYW WYBRANYCH PARAMETRÓW TECHNICZNYCH SYSTEMU NA ODBIÓR FAL RADIOWYCH
}

\begin{abstract}
Jacek Lukasz Wilk-Jakubowski
Politechnika Świętokrzyska, Katedra Systemów Informatycznych, Zakład Informatyki

Streszczenie. Artykuł omawia wpływ wybranych parametrów systemu na odbiór fal radiowych, co ma zastosowanie w optymalizacji systemów łaczności. Cel ten realizuje sie poprzez dobór parametrów technicznych urzadzeń np. współczynnika sprawności anteny odbiorczej. Zwięsszenie współczynnika dostępności dla danego systemu wiąze się z minimalizacja wplywu wielu niepożąanych czynników na transmisję fal radiowych (w tym tlumienia podstawowego oraz influencji klimatyczno-atmosferycznej). W rezultacie możliwe staje się zoptymalizowanie istniejących już systemów teletransmisyjnych oraz projektowanie nowych systemów, pozwalających na znaczna poprawę jakości $i$ wiarygodności przekazywanych informacji (zaprezentowane wyniki ogranicza się do częstotliwości z zakresu pasma Ku - powszechnie wykorzystywanego w tączności satelitarnej).
\end{abstract}

Słowa kluczowe: parametry techniczne, modelowanie obliczeniowe, thumienie sygnału, propagacja fal radiowych

\section{THE INFLUENCE OF SELECTED TECHNICAL PARAMETERS ON THE RECEPTION OF RADIO WAVES}

\begin{abstract}
This article presents the influence of selected parameters on the reception of radio waves to optimize communication systems. That goal is achieved by selection of technical parameters of system, eg. antenna efficiency. The result is to minimize the negative effects of free space propagation and induction of climate and Earth's atmosphere in order to increase the G/T figure. In practice, changes in the climatic and atmospheric conditions are significant factors affecting the quality of satellite signal. These results can be used by satellite systems engineers to calculate the link budget analyses of current and future systems through scientifically solid evaluation and assessment. So, these estimates may be useful to improve the design and performance of telematic networks, or to minimize the interruption or lack of communication between the terminal and the satellite in Ku band.
\end{abstract}

Keywords: technical parameters, computational modeling, signal attenuation, radio waves propagation

\section{Wstęp}

W praktyce istnieje wiele czynników przekładających się na odbiór fal radiowych. Jednym $\mathrm{z}$ nich jest tłumienie w wolnej przestrzeni propagacyjnej (ang. free space propagation), zwane również tłumieniem swobodnej przestrzeni oraz thumieniem podstawowym. Oprócz tego na rozchodzenie się fal radiowych wpływają różne od wyidealizowanego przypadku propagacji w wolnej przestrzeni warunki rozchodzenia się fal radiowych. W tym kontekście należy wskazać wpływ: (1) atmosfery ziemskiej (w tym czynników klimatyczno-atmosferycznych w niej zachodzących) [3, 5, 22, 25, 28, 41, 42]; (2) naturalnych źródeł szumów o podłożu ziemskim, jak i pozaziemskim $[4,7,23,27$, 28, 31, 32, 35, 36, 39, 42, 46, 47]; (3) strat wynikających z braku precyzji ustawienia anteny oraz (4) zastosowania rzeczywistych, stratnych elementów systemu odbiorczego (m.in. straty cyfrowej modulacji, całkowite straty w łączu, szumy fazowe konwertera LNB, nieliniowe charakterystyki filtrów w demodulatorze i stopnia mocy w satelicie, działanie dekoderów itp.) [2, 24, 37, 43]. W tym artykule przeanalizowano wpływ wybranych parametrów technicznych systemu odbiorczego, ze szczególnym uwzględnieniem współczynnika sprawności anteny, na odbiór fal radiowych, przy założeniu pozostałych parametrów jako niezmienne w czasie (ich standardowe wartości zostały podane w dalszej części artykułu). Wykorzystano model szacowania tłumienia sygnału spowodowanego wystąpieniem opadów deszczu zgodny z zaleceniami ITU-R [26, 40].

\section{Prowadzone badania}

W ostatnich latach stopień relewancji influencji meteorologiczno-środowiskowej - w związku z nasilającymi się anomaliami klimatycznymi oraz wyraźnie zauważalną niestabilnością meteorologiczną - uległ znaczącemu wzrostowi. Teledetekcja umożliwia modelowanie deszczu z wykorzystaniem technik GIS. Monitorowanie procesów kształtujących pogodę i klimat na Ziemi, analiza składu atmosfery ziemskiej oraz pomiary propagacyjne fal radiowych odgrywają zatem istotną rolę w kierunku dokładnego poznania wpływu rozmaitych mechanizmów i zjawisk na rozchodzenie się fal radiowych [8-10]. W tym kontekście działania te nabierają szczególnie ważnego znaczenia. Spośród wielu czynników klimatycznych uwydatnia się oddziaływanie deszczu - jako jednego $\mathrm{z}$ najważniejszych hydrometeorów [11-17]. Dla określonego natężenia opadów (zmierzonego zawartością wody) najważniejszy wpływ na thumienie fali radiowej, jak również jego depolaryzację ma deszcz (wpływ innych hydrometeorów jest zwykle pomijany). Dla kątów elewacji większych niż $10^{\circ}$ deszcz może być przyczyną kilkudziesięcio dB thumienia. Istotnym czynnikiem degradacji dla fal o częstotliwości rzędu kilkunastu $\mathrm{GHz}$ jest także absorpcja molekularna $w$ gazach atmosferycznych stanowiących składniki powietrza. Może ona wnosić tłumienie o wartości kilkunastu dB dla małych kątów elewacji [47]. W celu oszacowania wartości tłumienia można posłużyć się modelem regresji, który pozwoli określić przewidywaną degradację sygnału [33]. Zaproponowane przez autora krzywe propagacyjne bez konieczności znajomości Regulaminu Telekomunikacyjnego oraz rekomendacji ITU-R pozwalają oszacować np. wartość thumienia sygnału satelitarnego w obszarze Kielc, która odzwierciedla rzeczone tłumienie w obszarze Polski. W praktyce gęstość strumienia mocy na powierzchni Ziemi uzależniona jest od zysku anteny.

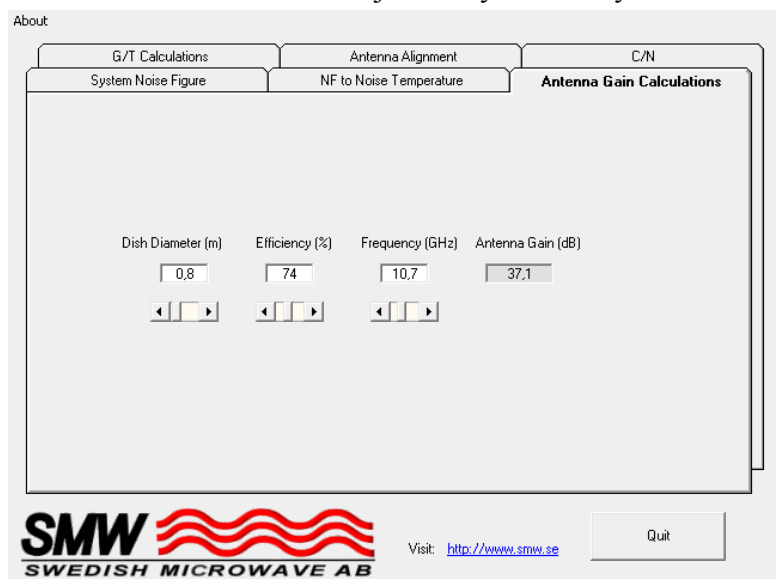

Rys. 1. Szacowanie zysku rzeczywistej anteny z wykorzystaniem oprogramowania SMW Link

Warto zaznaczyć, że natężenie opadów w obszarze Kielc jest reprezentatywne dla obszaru całej Polski $(34,4 \mathrm{~mm} / \mathrm{h})$ [45-47]. W Kielcach zrealizowano wiele badań również w ramach Europejskiego Projektu Badawczego ICT COST Action IC0802 "Propagation tools and data for integrated Telecommunication, Navigation and Earth Observation systems", w którym uczestniczyła Politechnika Świętokrzyska w Kielcach [19, 20, m.in. 31] 


\section{Lokalizacja stanowiska pomiarowego oraz parametry odbioru}

Do celów analizy wykorzystano model matematyczny systemu satelitarnego czwartej klasy dostępności, który pozwala na uzyskanie średniej dostępności w ciągu roku na poziomie $99,99 \%$ oraz $\mathrm{w}$ najgorszym miesiącu na poziomie $99,948 \%$, co odpowiada przestojowi równemu 0,877 godz. w skali roku oraz 0,379 godz. w skali najgorszego miesiąca. Wykorzystanie systemu satelitarnego pozwoliło uwzględnić nie tylko wpływ troposfery ziemskiej (istotny szczególnie dla naziemnych systemów łączności), ale również innych warstw atmosfery (propagacja transjonosferyczna) i zakłóceń od pozostałych systemów łączności (w modelu uwzględniono oddziaływanie sąsiednich systemów o parametrach EIRP $=51 \mathrm{dBW}$ (pasmo 26 i $33 \mathrm{MHz}$ ), w konsekwencji czego pojawiły się nieodzowne dla transmisji satelitarnej zakłócenia interferencyjne). Ponieważ zakłócenia pomiędzy wiązkami anten stanowią bardzo ważne źródło szumów w wielowiązkowych systemach łączności satelitarnej (powodują zwiększenie szumów termicznych), pominięcie ww. zakłóceń byłoby błędem. Gdy znana jest gęstość szumów, możliwe jest oszacowanie mocy szumów dla danej szerokości pasma (w odniesieniu do $1 \mathrm{~Hz}$ ). Ich wartość (wyrażająca stosunek całkowitej mocy sąsiednich sygnałów interferujących $\mathrm{z}$ danym kanałem w stosunku do mocy fali nośnej kanału oraz stosunek sumarycznej mocy sygnałów spolaryzowanych krzyżowo nakładających się na dany kanał do mocy fali nośnej kanału) przyjęto na poziomie $100 \mathrm{dBHz}$ (typowe wartości zawierają się w przedziale od 100 do $115 \mathrm{dBHz}$ ). Można korzystać w tym celu $\mathrm{z}$ wielu narzędzi, jak np. oprogramowanie licencyjne SatMaster firmy Arrowe.

Parametry miejsca odbioru (miasto Kielce) są następujące: 50,87N, 20,62E, wysokość $300 \mathrm{~m}$ n.p.m., kąt polaryzacji do odbioru sygnałów z satelity Astra 1KR: 7,6 $(19,2 \mathrm{E})$.

W celu określenia prawidłowego położenia anteny można wykorzystać mapy topograficzne, nadajnik GPS lub użyć dedykowanego oprogramowania, jak np. SMW Link (rys. 2).

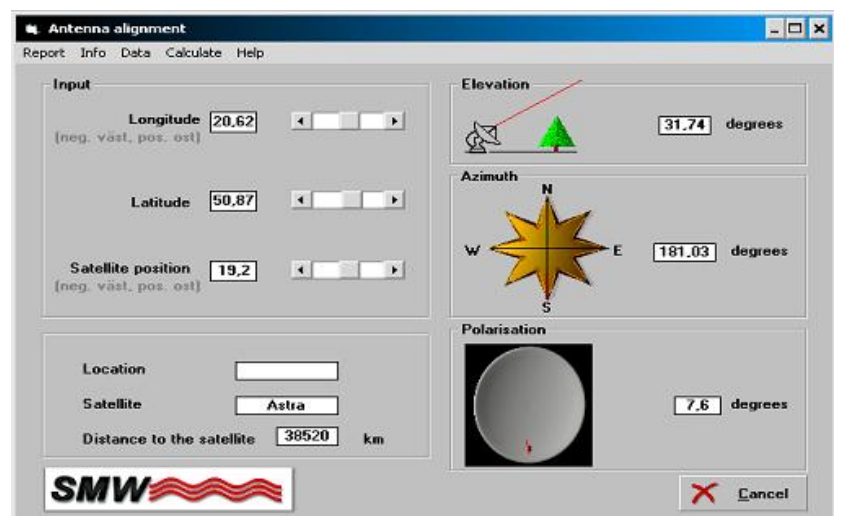

Rys. 2. Określenie kąta polaryzacji z wykorzystaniem oprogramowania SMW Link

W Polsce zaleca się do odbioru sygnałów z satelity Astra $1 \mathrm{KR}$ anteny o średnicy minimum $60 \mathrm{~cm}$ (do analiz wykorzystano antenę o średnicy $80 \mathrm{~cm}$ ) [1]. W tym celu posłużono się sygnałem spolaryzowanym poziomo (horyzontalnie) o częstotliwości $10,7 \mathrm{GHz}$ (dane satelity: EIRP $=51 \mathrm{dBW}$, pasmo $26 \mathrm{MHz}$ ). Wybór polaryzacji był nieprzypadkowy (w praktyce fale o polaryzacji poziomej sa znacznie bardziej thumione od fal o polaryzacji pionowej). W przypadku propagacji fal radiowych o polaryzacji horyzontalnej atmosfera ziemska nie wykazuje istotnego tłumienia w zakresie o częstotliwości $0,1-6 \mathrm{GHz}$, zaś dla fal o polaryzacji pionowej okno rozszerza się aż do $50 \mathrm{GHz}$. Istota znajomości wyników odzwierciedlających thumienie, wzrost szumów systemowych, degradacja czy depolaryzacja fali radiowej jest ważna na potrzeby projektowania optymalnych łączy telekomunikacyjnych.
Podobnie, istotne są parametry techniczne zastosowanych urządzeń na potrzeby modelowania komputerowego. Całkowite straty w łączu, straty wynikające $\mathrm{z}$ błędu wizowania anteny oraz współczynnik szumów konwertera LNB założono na poziomie $0,3 \mathrm{~dB}$.

Szumy nieba istotnie wpływają na stosunek mocy nośnej sygnału do mocy szumów CNR (ang. Carrier-to-Noise Ratio), co przekłada się na spadek poziomu nośnej oraz dobroci G/T (ang. antenna gain-to-noise-temperature figure), wyrażającej stosunek zysku energetycznego anteny do zastępczej temperatury szumów systemowych. Zwiększenie współczynnika dostępności (gotowości) G/T pozwala zredukować moc i vice versa. Zmniejszenie temperatury szumowej nieba oddziałuje na spadek temperatury szumowej systemu. Hydrometeory stanowią zatem swego rodzaju tłumik, będący źródłem szumów cieplnych, które dodają się jako wielkość addytywna do całkowitej degradacji sygnału. Znamienne jest to, że wielkość szumów termicznych przewyższa thumienie fali radiowej dla częstotliwości mniejszej niż $10 \mathrm{GHz}$

\section{Wyniki badań}

Poniżej zamieszczono tabelaryczne zestawienia ilustrujące wpływ współczynnika sprawności anteny w zakresie od $60 \%$ do $70 \%$ na zysk anteny, temperaturę szumową systemu oraz moc fali nośnej na wyjściu konwertera LNB (zwanego dalej wyjściem LNB) dla czystego nieba (pogoda bezdeszczowa).

Tabela 1. Wyniki modelowania obliczeniowego podczas pogody bezdeszczowej (brak opadów opadów)

\begin{tabular}{|c|c|c|c|}
\hline $\begin{array}{c}\text { Sprawność } \\
\text { anteny [\%] }\end{array}$ & $\begin{array}{c}\text { Zysk anteny } \\
{[\mathrm{dBi}]}\end{array}$ & $\begin{array}{c}\text { Temperatura szumów } \\
\text { systemowych [K] }\end{array}$ & $\begin{array}{c}\text { Moc fali nośnej na } \\
\text { wyjściu LNB [dBW] }\end{array}$ \\
\hline 60 & 36,9 & 82,43 & $-57,71$ \\
\hline 61 & 36,97 & 81,59 & $-57,64$ \\
\hline 62 & 37,04 & 80,75 & $-57,57$ \\
\hline 63 & 37,11 & 79,91 & $-57,5$ \\
\hline 64 & 37,18 & 79,07 & $-57,43$ \\
\hline 65 & 37,24 & 78,23 & $-57,37$ \\
\hline 66 & 37,31 & 77,39 & $-57,3$ \\
\hline 67 & 37,38 & 76,55 & $-57,23$ \\
\hline 68 & 37,44 & 75,71 & $-57,17$ \\
\hline 69 & 37,5 & 74,87 & $-57,11$ \\
\hline 70 & 37,57 & 74,03 & $-57,04$ \\
\hline
\end{tabular}

Wzrost współczynnika sprawności w zakresie 60-70\% przekłada się na zwiększenie zysku anteny (rys. 3). Anteny o dużym zysku energetycznym pozwalają częściowo skompensować wpływ niepożądanych czynników na odbiór fal radiowych (zysk anteny oprócz częstotliwości fali radiowej zależy również od średnicy anteny oraz od jej sprawności - rys. 1).

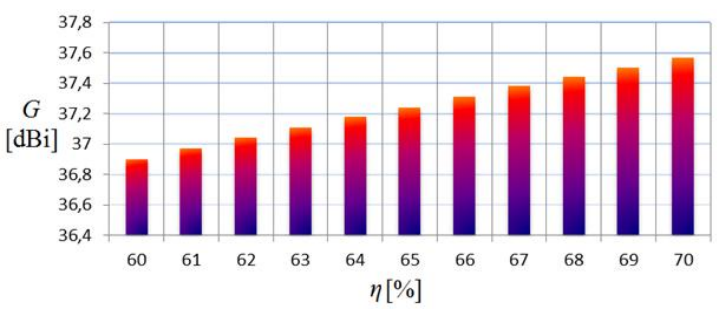

Rys. 3. Wplyw wspótczynnika sprawności anteny $\eta[\%]$ na zysk anteny $G$ [dBi]

Zwiększenie współczynnika sprawności anteny przekłada się na zmniejszenie niepożądanego wpływu temperatury szumowej systemu (rys. 4). Na jakość odbioru sygnałów oddziałują także szumy cieplne wewnątrz układów fizycznych (ang. thermal noise), które występują w każdym rezystorze oraz naturalne ziemskie i pozaziemskie źródła szumów [48]. Dla anteny naziemnej w odbiorniku źródło szumów stanowi promieniowanie nieba określone przez jego temperaturę luminancyjną (energia szumów cieplnych wzrasta wraz ze zwiększeniem temperatury). Z kolei dla anteny umieszczonej na satelicie źródło szumów o określonej temperaturze termodynamicznej stanowi Ziemia. 
Współczynnik sprawności anteny oddziałuje również na moc fali nośnej na wyjściu LNB (rys. 5). Na jej wartość wpływają ponadto czynniki niezwiązane $\mathrm{z}$ parametrami technicznymi systemu odbiorczego, jak np.: współrzędne geograficzne miejsca odbioru, ukształtowanie terenu, częstotliwość, thumienie podstawowe (w atmosferze)

W tabeli 2 przedstawiono analogiczne wyniki uzyskane podczas opadów deszczu.

Wystąpienie opadów deszczu nie wpływa na zwiększenie zysku anteny, dlatego też niezależnie od sytuacji meteorologicznej uzyskane wyniki są takie same (rys. 6). Dla współczynnika sprawności anteny w zakresie $60-70 \%$ (z krokiem równym $1 \%$ ) zysk anteny wynosi odpowiednio: 36,$90 ; 36,97 ; 37,04 ; 37,11$; 37,$18 ; 37,24 ; 37,31 ; 37,38 ; 37,44 ; 37,50 ; 37,57$.

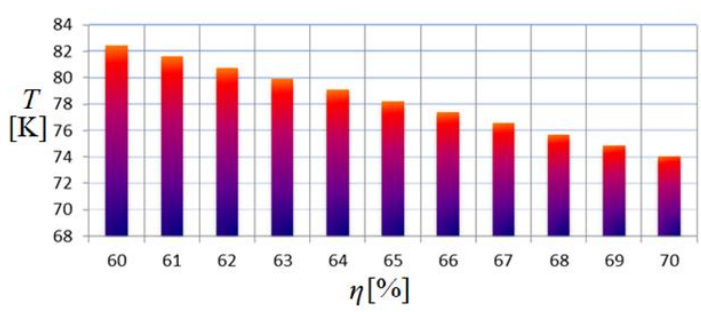

Rys. 4. Wplyw współczynnika sprawności anteny $\eta[\%]$ na temperaturę szumów systemowych $T[K]$

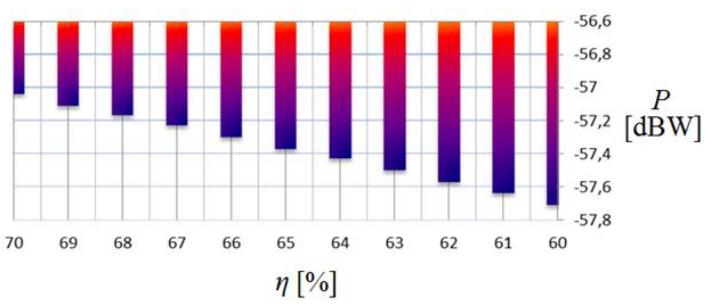

Rys. 5. Wplyw wspótczynnika sprawności anteny $\eta[\%]$ na moc fali nośnej $P$ na wyjściu $L N B[d B W]$

Tabela 2. Wyniki modelowania obliczeniowego podczas pogody deszczowej (opady deszczu)

\begin{tabular}{|c|c|c|c|}
\hline $\begin{array}{c}\text { Sprawność } \\
\text { anteny [\%] }\end{array}$ & $\begin{array}{c}\text { Zysk anteny } \\
{[\mathrm{dBi}]}\end{array}$ & $\begin{array}{c}\text { Temperatura szumów } \\
\text { systemowych [K] }\end{array}$ & $\begin{array}{c}\text { Moc fali nośnej na } \\
\text { wyjściu LNB [dBW] }\end{array}$ \\
\hline 60 & 36,9 & 87,17 & $-57,8$ \\
\hline 61 & 36,97 & 86,33 & $-57,73$ \\
\hline 62 & 37,04 & 85,49 & $-57,66$ \\
\hline 63 & 37,11 & 84,65 & $-57,59$ \\
\hline 64 & 37,18 & 83,81 & $-57,52$ \\
\hline 65 & 37,24 & 82,97 & $-57,45$ \\
\hline 66 & 37,31 & 82,13 & $-57,38$ \\
\hline 67 & 37,38 & 81,29 & $-57,32$ \\
\hline 68 & 37,44 & 80,45 & $-57,25$ \\
\hline 69 & 37,5 & 79,61 & $-57,19$ \\
\hline 70 & 37,57 & 78,77 & $-57,13$ \\
\hline
\end{tabular}

W przypadku wystąpienia opadów deszczu zauważalny jest wzrost temperatury szumów systemowych w stosunku do pogody bezdeszczowej (opady deszczu skutkują podwyższeniem temperatury szumów systemowych poprzez zwiększenie temperatury szumowej nieba). Opady deszczu stanowią zatem dodatkowe źródło szumów termicznych, powodując wzrost temperatury szumów systemowych o $4,74 \mathrm{~dB}-\mathrm{w}$ rozpatrywanym zakresie współczynnika sprawności anteny $60-70 \%$ - w stosunku do pogody bezdeszczowej (rys. 7).

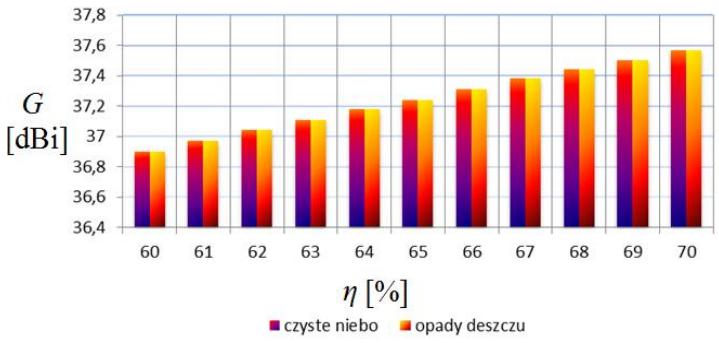

Rys. 6. Wpływ wspótczynnika sprawności anteny $\eta[\%]$ na zysk anteny $G[d B i]$ $w$ zależności od sytuacji meteorologicznej (pogoda deszczowa lub bezdeszczowa)
Zwiększenie sprawności anteny powoduje wzrost mocy fali nośnej na wyjściu konwertera LNB. Podczas opadów deszczu notuje się różnicę mocy fali nośnej na wyjściu LNB w stosunku do pogody bezdeszczowej o około $0.1 \mathrm{dBW}$. Podczas opadów deszczu dla współczynnika sprawności anteny od $60 \%$ do $70 \%$ odnotowano różnicę mocy fali nośnej na wyjściu LNB w stosunku do pogody bezdeszczowej na poziomie $0,008-0,09 \mathrm{dBW}$ (rys. 8).

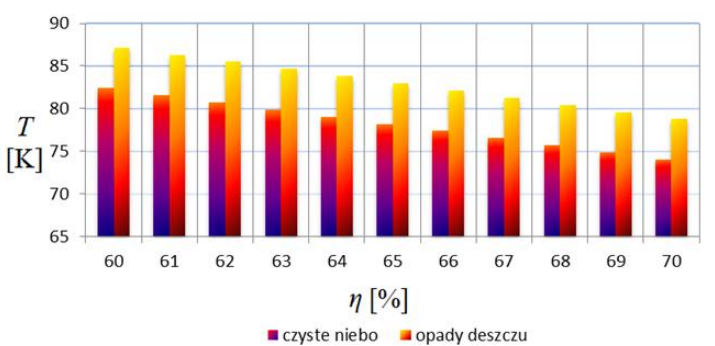

Rys. 7. Wpływ wspótczynnika sprawności anteny $\eta[\%]$ na temperaturę szumów systemowych $T[K]$ w zależności od sytuacji meteorologicznej (pogoda deszczowa lub bezdeszczowa)

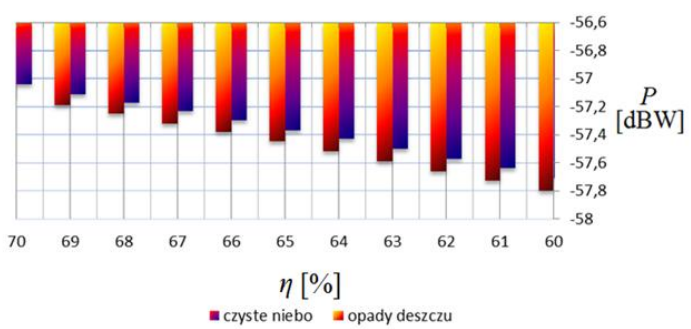

Rys. 8. Wplyw wspótczynnika sprawności anteny $\eta[\%]$ na moc fali nośnej $P$ na wyjściu $L N B[d B W]$ w zależności od sytuacji meteorologicznej (pogoda deszczowa lub bezdeszczowa)

\section{Podsumowanie}

Obecnie przedmiotem współpracy wielu placówek akademickich, instytucji naukowych oraz jednostek rządowych państw Europy i całego świata jest tworzenie możliwie najbardziej skutecznych, niezawodnych technologiczno-organizacyjnych mechanizmów teletransmisyjnych, które będą zdatne do prawidłowego funkcjonowania niezależnie od zagrożeń integralności powszechnych systemów radiokomunikacji i transmisji danych. W ramach potencjalnych niebezpieczeństw można wyodrębnić zarówno zagrożenia antropogeniczne, jak i wynikające $z$ oddziaływania wielu czynników klimatycznoatmosferycznych wymienionych $w$ artykule. Odpowiedzią na powyższe wyzwania jest zapewnienie łączności, relatywnie odpornej na opisane wyżej czynniki ryzyka, mogącej w sytuacjach krytycznych - nieprzerwanie funkcjonować z zadeklarowaną niezawodnością. Ponadto systemy takie $\mathrm{z}$ wykorzystaniem satelitów - mogą w przypadku zagrożenia (akty terrorystyczne, sabotaż, konflikty zbrojne) $\mathrm{z}$ powodzeniem substytuować infrastrukturę naziemną. Jednym z takich projektów jest Europejski Projekt Badawczy ICT COST Action IC0802 "Propagation tools and data for integrated Telecommunication, Navigation and Earth Observation systems" [19, 20], którego celem było m.in. testowanie modeli deterministycznych w odniesieniu do statystycznych obliczeń [4, 7]. Tego typu badania przeprowadzono również w Polsce, w reprezentatywnym ze względu na warunki klimatyczno-atmosferyczne obszarze Kielc. Ponieważ zmiana parametrów technicznych łącza odbiorczego przekłada się na zmianę jakości odbioru sygnałów radiowych, pożądane wydaje się być dalsze prowadzenie tego typu analiz pod kątem optymalizacji istniejących już systemów teletransmisyjnych oraz projektowania nowych systemów, pozwalających na znaczną poprawę jakości i wiarygodności odbieranych sygnałów. W oparciu o przeprowadzone badania możliwe staje się oszacowanie „zapasu sygnałowego”, a tym samym zminimalizowanie ryzyka utraty łączności satelitarnej wskutek wystąpienia niepożądanych zjawisk, co globalnie przekłada się na rozwój technologii TIK, w tym również sieci satelitarnych [18, 21, 29, 30, 34, 38, 44]. 


\section{Literatura}

[1] Astra $1 \mathrm{KR}$ - footprints (mapa pokrycia satelity Astra $1 \mathrm{KR}$ ). Available online: https://www.ses.com/network/satellites/335 [05.04.2018].

[2] Baghsiahi H., Wang K., Kandulski W., Pitwon R., Selviah D.: Optical waveguide end facet roughness and optical coupling loss. Journal of Lightwave Technology 31(16), 2013, 2659-2668, [DOI: 10.1109/JLT.2013.2271952].

[3] Bem J.: Anteny i rozchodzenie się fal radiowych. Wydawnictwa NaukowoTechniczne. Warszawa 1973.

[4] Benarroch A., García-del-Pino P., García-Rubia J. M., Riera J. M.: Derivation of rain attenuation from experimental measurements of drop size and velocity distributions. COST IC0802 (MCM3). Available online: http://www.tesa. prd.fr/cost/input_documents.pdf [05.04.2018].

[5] Bogucki J.: Anteny łączności satelitarnej. Bezpieczeństwo pracy 6, 2011, 6-10.

[6] Bogucki J.: Trasy nachylone w zakresie fal milimetrowych. Telekomunikacja i Techniki Informacyjne 3/4, 2003, 66-92.

[7] Boulanger X., Castanet L., Jeannin N., Lacoste F.: Study and modelling of tropospheric attenuation for land mobile satellite system operating at $\mathrm{Ku}$ and $\mathrm{Ka}$ band. COST IC0802 (MCM2). Available online: http://www.tesa. prd.fr/cost/input_documents.pdf [06.04.2018].

[8] Cetin M., Adiguzel F., Kaya O., Sahap A.: Mapping of bioclimatic comfort for potential planning using GIS in Aydin. Environment, Development and Sustainability, in press, 2016, 1-15. Available online: http://link.springer.com/ article/10.1007/s10668-016-9885-5 [06.04.2018]

[9] Cetin M.: Consideration of permeable pavement in Landscape Architecture. Journal of Environmental Protection and Ecology 16(1), 2015, 385-392. Available online: https://docs.google.com/a/jepe-journal.info/viewer?a=v\&pid= sites\&srcid=amVwZS1qb3VybmFsLmluZm98amVwZS1qb3VybmFsfGd4OjN mY2FkYzYzN2Y1MWNIYjM [08.05.2018].

[10] Cetin M : Determination of bioclimatic comfort areas in landscape planning: A case study of Cide Coastline. Turkish Journal of Agriculture-Food Science and Technology 4(9), 2016, 800-804.

[11] Cetin M.: Determining the bioclimatic comfort in Kastamonu City. Environmental Monitoring and Assessment 187(10), 2015, 640. Available online: http://link.springer.com/article/10.1007\%2Fs10661-015-4861-3 [08.05. 2018]

[12] Cetin M.: Evaluation of the sustainable tourism potential of a protected area for landscape planning: a case study of the ancient city of Pompeipolis in Kastamonu. International Journal of Sustainable Development \& World Ecology 22(6), 2015, 490-495.

[13] Cetin M., Sevik H.: Assessing potential areas of ecotourism through a case study in Ilgaz Mountain National Park, ed. L. Butowski. InTech. Rijeka 2016. Available online: http://www.intechopen.com/books/tourism-from-empiricalresearch-towards-practical-application/assessing-potential-areas-of-ecotourismthrough-a-case-study-in-ilgaz-mountain-national-park [08.05.2018]

[14] Cetin M., Sevik H.: Evaluating the recreation potential of Ilgaz Mountain National Park in Turkey. Environmental Monitoring and Assessment 188(1), 2015, 52. Available online: http://link.springer.com/article/10.1007\% 2Fs10661015-5064-7 [08.05.2018].

[15] Cetin M.: Sustainability of urban coastal area management: a case study on Cide. Journal of Sustainable Forestry 35(7), 2016, 527-541, [DOI: 10.1080/10549811.2016.1228072]

[16] Cetin M., Topay M., Kaya L. G., Yilmaz B.: Efficiency of bioclimatic comfort in landscape planning process: case of Kutahya. Turkish Journal of Forestry 1(1), 2010, 83-95.

[17] Cetin M.: Using GIS analysis to assess urban green space in terms of accessibility: case study in Kutahya. International Journal of Sustainable Development \& World Ecology 22(5), 2015, 420-424, [DOI:10.1080/13504509.2015.1061066].

[18] Ciosmak J.: Algorytm wyznaczania nieseparowalnych dwuwymiarowych zespołów filtrów dla potrzeb systemów transmultipleksacji. Przegląd Elektrotechniczny 87(11), 2011, 217-220.

[19] EUROPEAN COOPERATION IN THE FIELD OF SCIENTIFIC AND TECHNICAL RESEARCH - COST: Final evaluation Report: Propagation Tools and Data for Integrated Telecommunication, Navigation and Earth Observation Systems. Available online: http://w3.cost.eu/fileadmin/domain files/ICT/Action_IC0802/final_report/final_report-IC0802.pdf [09.05.2018]

[20] EUROPEAN COOPERATION IN THE FIELD OF SCIENTIFIC AND TECHNICAL RESEARCH - COST: Memorandum of Understanding for the implementation of a European Concerted Research Action designated as COST Action IC0802: Propagation tools and data for integrated Telecommunication, Navigation and Earth Observation systems. Available online: http://w3.cost.eu/fileadmin/domain_files/ICT/Action_IC0802/mou/IC0802-e.pdf [09.05.2018]

[21] Heiser D. A., Keyser R. B.: Microwave measurements for antenna randome maintenance and replacement. IEEE Conference Publications. Symposium on Antenna Technology and Applied Electromagnetics 1, 1998, 501-506, [DOI: 10.1109/ANTEM.1998.7861713].

[22] Ho Ch., Kantak A., Slobin S., Morabito D.: Atmospheric attenuation and noise temperature effects. The Interplanetary Network Progress Report 42-168, 2007, $1-22$.

[23] Ho Ch., Kantak A., Slobin S., Asmar S.: Solar brightness temperature and corresponding antenna noise temperature at microwave frequencies. The Interplanetary Network Progress Report 42-175, 2008, 1-11.

[24] Huo X., Li D., Han X., Wang J.: Effects of structural and environmental parameters on the coupling loss of leaky rectangular waveguide in tunnel. Antennas \& Propagation Conference (LAPC), 2015, [DOI: 10.1109/LAPC 2015.7366022].
[25] Ippolito L. J.: Satellite communications. Systems engineering. Atmospheric effects, satellite link design and system performance. John Wiley \& Sons. Chichester 2008.

[26] ITU-R: Radio Regulations. Edition of 2017. Available online: http://www.itu.int/en/ publications/ITU-R/Pages/default.aspx [10.05.2018]

[27] Johannsen K. G., Koury A.: The moon as a source for G/T measurements. IEEE transactions on aerospace and electronic systems AE-S10(5), 1974, 718-727.

[28] Knoch L. (red.): Systemy radiokomunikacji satelitarnej. Wydawnictwa Komunikacji i Łączności. Warszawa 1980.

[29] Loska A.: Scenario modeling exploitation decision-making process in technical network systems. Eksploatacja I Niezawodność - Maintenance and Reliability 19(2), 2017, 268-278, [DOI: 10.17531/ein.2017.2.15].

[30] Lozano A., Tulino A. M.: Capacity of multiple-transmit multiple-receive antenna architectures. IEEE Transactions on Information Theory 48(12), 2002, 3117-3128, [DOI: 10.1109/TIT.2002.805084].

[31] Marciniak M., Wilk J.: Czynniki thumienia fal radiowych w atmosferze ziemskiej. Logistyka 4, 2015, 6578-6588.

[32] Marciniak M., Wilk J.: Relationship between the quality coefficients signal and rainfall intensity. TRANSCOM 2015. 11-th European conference of young researchers and scientists 3,2015, 94-98.

[33] Marek M.: Wykorzystanie ekonometrycznego modelu klasycznej funkcji regresji liniowej do przeprowadzenia analiz ilościowych w naukach ekonomicznych. Rola informatyki w naukach ekonomicznych i społecznych. Innowacje i implikacje interdyscyplinarne. The role of informatics in economic and social sciences. Innovations and interdisciplinary implications, ed. T. Grabiński. Wydawnictwo Wyższej Szkoły Handlowej im. B. Markowskiego w Kielcach. Kielce 2013.

[34] Mohseni M., Zhang R., Cioffi J. M.: Optimized transmission for fading multiple-access and broadcast channels with multiple antennas. IEEE Journal on Selected Areas in Communications 24(8), 2006, 1627-1639, [DOI: 10.1109/JSAC.2006.879407].

[35] Natrov D. M., Marciniak M., Sauleau R., Nosich A. I.: Effect of Periodicity in the Resonant Scattering of Light by Finite Sparse Configurations of Many Silver Nanowires. Plasmonics 9(2), 2014, 389-407.

[36] Nosich A. I., Marciniak M., Zinenko T. L.: Accurate Analysis of Light Scattering and Absorption by an Infinite Flat Grating of Thin Silver Nanostrips in Free Space Using the Method of Analytical Regularization. IEEE Journal of Selected Topics in Quantum Electronics 19(3), 2013, 1-8.

[37] Pardo E., Kapolka M., Kováč J., Šouc J., Grilli F., Piqué A. Three-Dimensional Modeling and Measurement of Coupling AC Loss in Soldered Tapes and Striated Coated Conductors. IEEE Transactions on Applied Superconductivity 26(3), 2016, [DOI: 10.1109/TASC.2016.2523758]

[38] Pilch R.: Reliability evaluation of networks with imperfect and repairable links and nodes. Eksploatacja i Niezawodność - Maintenance and Reliability 19(1), 2017, 19-25, [DOI: 10.17531/ein.2017.1.3]

[39] Rec. P. 372-10: Radio noise. ITU-R. Genewa 2009.

[40] Rec. P. 837-6: Characteristics of precipitation for propagation modeling. Radio noise. ITU-R. Genewa 2012

[41] Roddy D.: Satellite communications. McGraw-Hill. New York 2001

[42] Szóstka J.: Fale i anteny. Wydawnictwa Komunikacji i Łączności. Warszawa 2006.

[43] Weitzen J. A.: Effects of polarization coupling loss mechanism on design of meteor scatter antennas for short- and long-range communication. Radio Science 24(4), 1989, 549-557, [DOI: 10.1029/RS024i004p00549]

[44] Wilk-Jakubowski G.: Wpływ technologii informatyczno-komunikacyjnych na funkcjonowanie współczesnych społeczeństw. Rola informatyki w naukach ekonomicznych i społecznych. Innowacje i implikacje interdyscyplinarne. The role of informatics in economic and social sciences. Innovations and interdisciplinary implications, ed. T. Grabiński. Wydawnictwo Wyższej Szkoły Handlowej im. B. Markowskiego w Kielcach. Kielce 2011.

[45] Wilk-Jakubowski J.: Badanie niezawodności satelitarnych systemów teleinformatycznych $\mathrm{w}$ warunkach propagacji $\mathrm{w}$ atmosferze ziemskiej. TTS. Technika transportu szynowego 12, 2016, 364-367.

[46] Wilk-Jakubowski J.: Ocena wpływu źródeł szumów naturalnych na propagacje fal radiowych. Autobusy. Technika, Eksploatacja, Systemy Transportowe 12, 2016, 1450-1453

[47] Wilk-Jakubowski J.: Wpływ warunków klimatyczno-atmosferycznych na mechanizm propagacji fal radiowych $w$ atmosferze ziemskiej. TTS. Technika transportu szynowego 12, 2016, 266-268.

[48] Zieliński R. J.: Satelitarne sieci teleinformatyczne. Wydawnictwa NaukowoTechniczne. Warszawa 2009

\section{Dr inż. Jacek Lukasz Wilk-Jakubowski}

e-mail: j.wilk@tu.kielce.pl

Na Politechnice Świętokrzyskiej ukończył zarówno studia magisterskie w 2009 r. (na kierunku Elektrotechnika), jak i studia doktoranckie w $2013 \mathrm{r}$. (w dyscyplinie Elektrotechnika). Autor wielu publikacji naukowych (w tym: monografii, rozdziałów, artykułów), w których podejmuje tematyke ICT dotyczaca optymalizacji systemów zarządzania kryzysowego i transmisji danych w przypadku wystąpienia niekorzystnych zjawisk, w tym klęsk żywiołowych. Uczestnik wielu konferencji krajowych i zagranicznych.

otrzymano/received: 11.06 .2018 